\title{
Aklimasi siebenrockiella crassicollis yang Akan Dikonservasi di Area ex situ Universitas Bengkulu
}

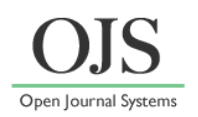

\author{
Jabidi $^{1}{ }^{*}$, Aceng Ruyani ${ }^{1}$, Hery Suhartoyo ${ }^{2}$ \\ ${ }^{1}$ Program Pascasarjana S2 Pendidikan IPA Universitas Bengkulu, Indonesia \\ ${ }^{2}$ Jurusan Kehutanan Universitas Bengkulu, Indonesia \\ *Email: sjabidi@yahoo.com
}

DOI: https://doi.org/10.33369/pendipa.v3i1.6927

\begin{abstract}
[Acclimation of Siebenrockiella crassicollis in Conservation Area Ex Situ at Bengkulu University]. This study aims to determine the effect of pool water composition on the growth rate of $S$. crassicollis, which will be conservated in ex situ area of Bengkulu University campus. The turtles initially acclimated in the Sumber Belajar Ilmu Hayati (SBIH) Ruyani Bengkulu. The result of this research shows 50\% of well water $+50 \%$ of pond water has the highest growth rate of $S$. crassicolis, but the difference of growth rate in each treatment group does not look different significantly. Thus, the pond water in the ex situ area of Bengkulu University can be recommended for use as an Ex situ Conservation site for S. Crassicollis.
\end{abstract}

Keywords: S. crassicolis; water pond; student work sheet.

(Received August 10, 2018; Accepted January 9, 2019; Published February 27, 2019)

\begin{abstract}
ABSTRAK
Penelitian ini bertujuan untuk mengetahui pengaruh pemberian komposisi air kolam terhadap laju pertumbuhan S.crassicollis, yang akan di konservasi di area ex situ Universitas Bengkulu. Penelitian ini telah dilakukan pada Maret 2017 - April 2017, diaklimasi di Sumber Belajar Ilmu Hayati (SBIH) Ruyani Bengkulu. Hasil penelitian ini adalah pemberian 50\% air sumur $+50 \%$ air kolam memiliki tingkat laju pertumbuhan $S$. crassicolis paling tinggi,namun perbedaan rata-rata laju pertumbuhan pada setiap kelompok perlakuan tidak terlihat berbeda signifikan/tidak berbeda nyata. Sehingga, air kolam di area ex situ Universitas Bengkulu dapat direkomendasikan untuk digunakan sebagai lokasi konservasi Ex situ bagi S. crassicolis.
\end{abstract}

Kata kunci : S. crassicolis; air kolam; lembar kerja siswa.

\section{PENDAHULUAN}

Kura-kura Pipi Putih Siebenrockiella crassicollis adalah salah satu jenis kura-kura yang akan dikonservasi di area ex situ Universitas Bengkulu. Kura-kura ini termasuk jenis yang berukuran kecil, karena ukuran terbesar yang pernah dijumpai hanya mencapai $200 \mathrm{~mm}$. pertumbuhannya sangat lambat hanya beberapa millimeter pertahun (Iskandar,2000). Perubahan dan kehilangan habitat diduga telah mengancam kelestarian jenis ini, ditambah lagi dengan tekanan penangkapannya di alam untuk diperdagangkan. International Union ForConservation Of Nature (IUCN), telah memasukkan kura-kura pipi putih
(S. crassicollis) kedalam kategori Rentan (VU, vulnerable). Menurut IUCN, Rentan (VU, vulnerable) adalah suatu spesies dengan resiko punah dalam jangka menengah, dan beresiko menjadi genting. Dalam praktiknya yang dimasukkan ke dalam golongan ini adalah spesies yang dalam 100 tahun memiliki resiko kepunahan lebih besar dari $10 \%$.

S. crassicollis merupakan kura-kura local yang hidup di air tawar anggota suku Geoemydidae. Kura-kura ini memiliki bentuk tepi rahang (bibir) atas yang melengkung menyerupai 
senyuman pada bagian samping wajah (pipi) dan ada bagian yang berwarna putih. Jumlah populasi yang semakin berkurang inilah sehingga perlu dilakukan konservasi. Untuk mengetahui laju pertumbuhan $S$. crassicollis yang akan di konservasi di area ex situ UNIB ini maka perlu dilakukan penelitian aklimasi. Menurut Indrawan (2012), bahwa program ex situ merupakan bagian tak terpisahkan dari strategi konservasi terpadu untuk melindungi hewan terancam dan sarana belajar bagi masyarakat. Konservasi ex situ kurakura yang dilakukan di area kampus UNIB ini disamping untuk upaya pelestarian juga dapat dimanfaatkan sebagai sumber belajar.

\section{METODE PENELITIAN}

Penelitian ini dilaksanakan pada bulan Maret 2017 - April 2017, diaklimasi di Sumber Belajar Ilmu Hayati Ruyani (SBIH Ruyani) Bengkulu. Pada penelitian Uji air kolam, disiapkan 16 ekor kura-kura yang masing-asing 4 ekor pada 4 jenis kelompok perlakuan dan kemudian diletakkan pada ember/bak plastic. Penelitian ini dilaksanakan dalam beberapa tahapan antara lain: 1) Pengukuran dilakukan dengan cara penimbangan dan pengukuran panjang, lebar dan tebal badan $S$. crassicollis sebagai data awal sebelum dilepaskan dalam ember/bak plastic. Selanjutnya ditentukan komposisi campuran air pada masing-masing wadah. 2) Tiap-tiap ember/bak plastic diangkat tiga hari sekali atau dua kali seminggu untuk mengganti air, sementara penimbangan dan pengukuran panjang, lebar, dan tebal tubuh kurakura dilakukan satu minggu sekali sehingga selama periode penelitian total pengukuran sebanyak 6 kali, untuk menghitung laju pertumbuhan tiap-tiap S.crassicollis.

\section{HASIL DAN PEMBAHASAN}

Efek Laju Pertumbuhan Berat Badan (LPBB) S. Crassicollis

Pengukuran terhadap pertumbuhan terlihat bahwa hanya perlakuan P2 (50\% air sumur $+50 \%$ air kolam) yang secara positif tetap mengalami kenaikan berat badan di setiap minggu penggamatan walaupun dalam skala yang kecil, sedangkan perlakuan lainnya (P1, P3 dan P4) secara rata-rata mengalami penurunan berat badan pada pengukuran di setiap minggu pengamatan yang ditandai dengan nilai negatif pada laju pertumbuhan berat badan. Namun demikian, perbedaan di setiap perlakuan secara rata-rata tidak terlihat signifikan, sehingga penggunaan air kolam masih dapat ditolerir sebagai lingkunganpengganti habitat $S$. crassicolis yang nantinya akan menjadi area lingkungan konservasi.

Pengukuran berat badan $S$. crassicolis selama 6 pekan di SBIH terlihat bahwa berat badan yang diukur mengalami fluktuasi yaitu terjadinya kenaikan dan penurunan berat badan pada setiap perlakuan pada setiap pengamatan. Pada proses aklimasi, suatu spesies diharuskan untuk dapat mencocokkan kondisi fisiologis terhadap lingkungan yang baru untuk mendukung pertumbuhan sel dan jaringan. Ketika suatu lingkungan berubah, suatu spesies harus melibatkan pengeluaran energi yang cukup besar agar terhindar dari seleksi alam (Angilletta, 2014). Pertumbuhan S. Crassicollis dapat dilihat pada Gambar 1.

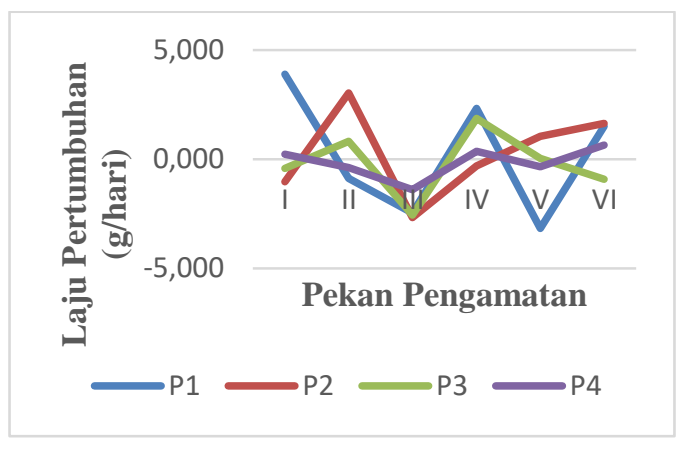

Gambar 1. Laju pertumbuhan Berat Badan (LPPB) S. Crassicollis selama 6 Pekan

Laju Pertumbuhan Panjang Lengkung (LPPL) S. Crassicollis

Pengukuran rata-rata pertumbuhan panjang lengkung karapaks $S$. crassicolis pada setiap variasi perlakuan media air tidak secara signifikan 
terlihat perbedaan, ini dikarenakan kualitas air yang di berikan pada setiap perlakuan memiliki nilai kualitas yang mendekati sama baik itu suhu, pH dan kadar oksigen yang terlarut di dalamnya. Menurut Riani (2012), kuantitas dan kualitas air sangat berpengaruh terhadap spesies dan jaringjaring kehidupan di dalamnya. Dengan demikian penggunaa air kolam di nilai cocok sebagai habitat alami pengganti $S$. crassicolis.

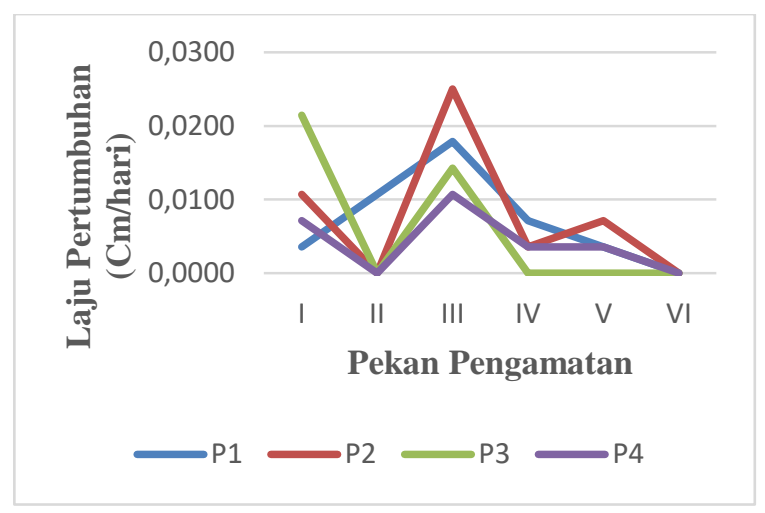

Gambar 2. Laju pertumbuhan panjang lengkung karapaks selama 6 pekan di SBIH Ruyani.

Berdasarkan gambar 2 atas menunjukkan bahwa untuk panjang lengkung karapaks terlihat pola grafik P2, P3 dan P4 semakin fluktuaktif pada minggu pengamatan kedua (II). Pada minggu ini kemungkinan kura-kura lebih mengoptimalkan kinerja fisiologis seperti suhu tubuh, kelenjar dan hormone untuk beradaptasi terhadap lingkungan, sehingga peningkatan atau perkembangan fisik cenderung di hentikan. Berbeda halnya dengan perlakuan yang di berikan air kolam, perlakuan P1 yang di berikan $100 \%$ air sumur tidak mengalami gangguan pada perkembangan fisik, terlihat pada gambar pola grafik perlakuan $\mathrm{P} 1$ cenderung konstan, ini juga mengindikasikan bahwa air sumur merupakan media perlakuan yang sudah adaptif bagi kurakura. Namun, di minggu selanjutnya yaitu minggu pengamatan keempat (IV) pertumbuhan panjang lengkung karapaks kura-kura dengan perlakuan P2, P3 dan P4 menjadi cenderung konstan hingga minggu terakhir pengamatan (minggu VI). Hal ini dapat disimpulkan kura-kura telah mulai beradaptasi dengan air kolam sejak minggu pengamatan keempat (IV). Proses ini sebagai akibat dari kemampuan makhluk hidup untuk menghadapi lingkungannya dengan mengadaptasikan fisiologis, struktur dan pola perilakunya (Odum, 1971). Menurut Highfield (2007), fakor yang mempengaruhi perkembangan kura-kura adalah air dan suhu, kondisi air yang baik dapat mengoptimalkan perkembangan dan pertumbuhan spesies di dalamnya. Dengan demikian, berdasarkan data tersebut, air kolam merupakan lingkungan alternative yang dapat digunakan sebagai habitat pengganti $S$. crassicolis dari habitat alami diasalnya dalam upaya konservasi.

\section{Laju Pertumbuhan Lebar Karapak S. Crassicollis}

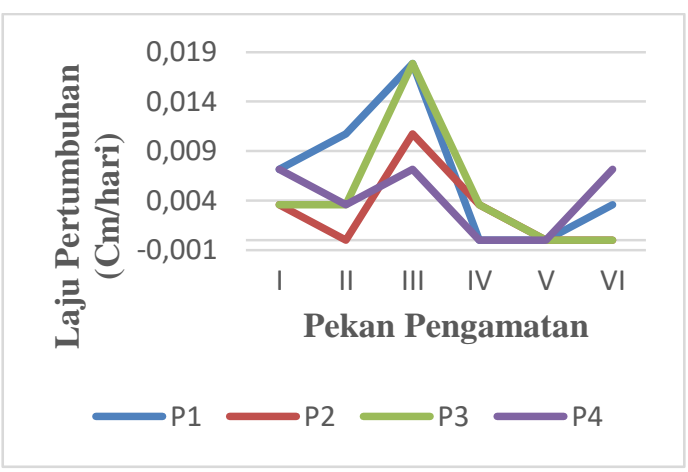

Gambar 3. Laju Pertumbuhan Lebar karapak S.crassicollis selama 6 pekan di SBIH Ruyani

Berdasarkan gambar 3 dapat dilihat bahwa pada lebar karapaks tertinggi terjadi pada P1 (100 $\%$ air sumur) yaitu $0.0065 \mathrm{Cm} /$ hari disusul P3 yaitu $0,0048 \mathrm{Cm} /$ hari, sedangkan rata-rata terendah terjadi pada P2 (50\% air kolam $+50 \%$ air sumur) yaitu $0,0030 \mathrm{Cm} / \mathrm{hari}$. Dapat dilihat bahwa lebar lengkung karapaks pada setiap pengamatan ada yang mengalami kenaikan dan ada yang tetap, berdasarkan perbandingan perlakuan air. Berdasarkan tabel diatas dapat diketahui pemberian air mana yang paling sesuai bagi pertumbuhan $S$. Crassichollis. Dapat dilihat 
bahwa rata-rata laju pertumbuhan lebar karapaks setiap perlakuan cenderung sama dan tidak terlalu signifikan. Maka pemberian air kolam cocok untuk S. Crassicholllis dan bisa direkomendasikan untuk pengganti habitatnya.

\section{Laju Pertumbuhan Panjang Karapaks (LPPK) S.} Crassicollis

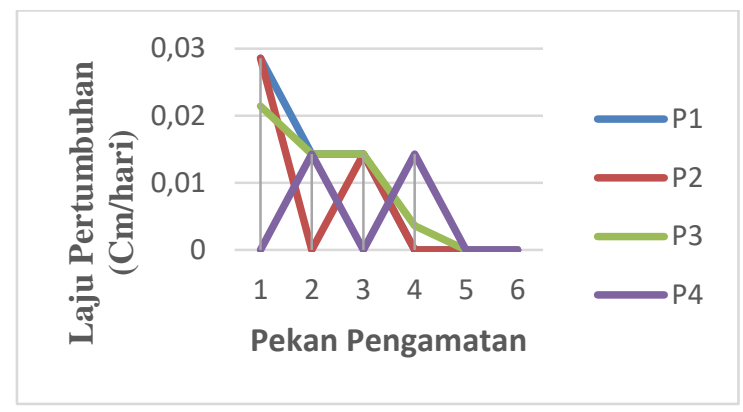

Gambar 4. Panjang karapak S. crassicollis selama 6 pekan di SBIH Ruyani; P1 $=100 \%$ air sumur, $\mathrm{P} 2=50 \%$ air sumur $+50 \%$ air kolam, $\mathrm{P} 3=75 \%$ air kolam $+25 \%$ air sumur, $\mathrm{P} 4=100 \%$ air kolam.

Berdasarkan Gambar 4 dapat dilihat bahwa laju pertumbuhan panjang karapaks (LPPK) $S$. crassicollis, pada kelompok perlakuan 1 (P1) ratarata laju pertumbuhan panjang karapaksnya sebesar $0.00952 \mathrm{Cm} /$ hari ini merupakan rata-rata laju pertumbuhan panjang karapaks yang paling besar dan di ikuti kelompok perlakuan 3 (P3), (P2) dan yang mengalami laju pertumbuhan panjang karapaks paling kecil adalah kelompok Perlakuan 4 (P4) yaitu sebesar $0.00476 \mathrm{Cm} /$ hari. Laju pertumbuhan panjang karapaks pada $S$. crassicollis dipengaruhi oleh faktor makanan, karena pada saat penelitian ada beberapa ekor $S$. crassicollis yang terlihat tidak suka makan karena makanan yang diberikan selalu ada sisahnya, makanya pada beberapa kali pengamatan ada yang tidak mengalami pertumbuhan panjang karapaks dan pada $S$. crassicollis pertumbuhan panjang karapaks ini sangatlah lambat dan hal ini juga dipengaruhi oleh tingkat sensitifitas kura-kura itu sendiri.

\section{Laju Pertumbuhan Tebal Badan (LPTB) S.}

\section{Crassicollis}

Setelah dilakukan pengkuran dapat kita lihat bahwa laju pertumbuhan tebal badan (LPTB) kura-kura $S$. crassicollis bersifat reversible karena pada beberapa kali pengamatan ada yang mengalami penurunan tebal badan. Laju pertumbuhan tebal badan $S$. crassicollis sangat dipengaruhi oleh faktor berat badan, jika berat badan meningkat maka laju pertumbuhan tebal badan juga akan meningkat begitu juga sebaliknya. Sedangkan pada laju pertumbuhan tebal badan yang mengalami penurunan kemungkinan penyebabnya adalah tingkat sensitifitas pada S. crassicollis selama dilakukan penelitian. Meskipun begitu faktor media air kolam dan air sumur semuanya dapat di pakai karena pada rata-rata laju pertumbuhan semuanya mengalami pertumbuhan walaupun angkanya tidakterlalu tinggi, dan selama dilakukan penelitian kura-kura S. crassicollis tidak ada yang mengalami kematian.

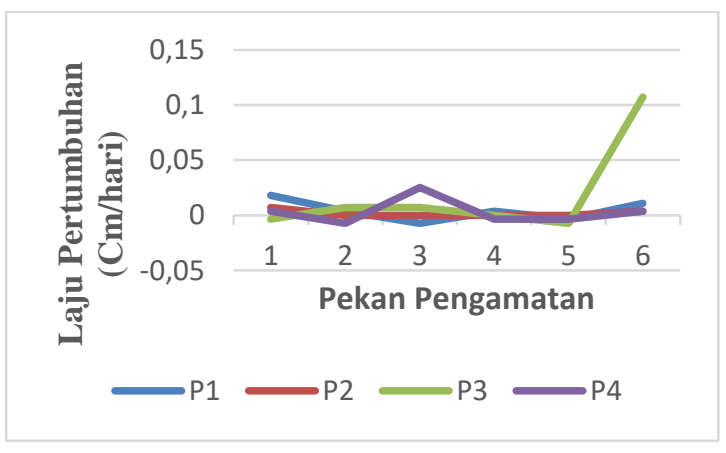

Gambar 5. Tebal karapakS. crassicollis selama 6 pekan di SBIH Ruyani $\mathrm{P} 1=100 \%$ air sumur, $\mathrm{P} 2=$ $50 \%$ air sumur $+50 \%$ air kolam, $\mathrm{P} 3=75 \%$ air kolam $+25 \%$ air sumur, $\mathrm{P} 4=100 \%$ air kolam.

Berdasarkan gambar 5 di atas dapat dilihat perbedaan rata-rata laju pertumbuhan tebal badan pada setiap kelompok perlakuan tidak begitu jauh berbeda hal ini dikarenakan bahwa air sumur dan air kolam yang digunakan sebagai variabel pada penelitian ini kedua-duanya bisa digunakan sebagai lingkungan pengganti habitat $S$. 
crassicollis yang nantinya akan menjadi area lingkungan konservasi Universitas Bengkulu.

\section{Laju Pertumbuhan Lebar Lengkung Karapaks}

\section{(LPLLK) S. Crassicollis}

Laju pertumbuhan lebar lengkung (LPLLK) $S$. crassicollispada kelompok perlakuan I (P1) laju pertumbuhan lebar lengkung paling tinggi terjadi pada pengamatan minggu ke II yaitu sebesar 0.025 $\mathrm{Cm} /$ hari. Sedangkan laju pertumbuhan lebar lengkung karapaks yg paling kecil yaitu terjadi pada pengamatan minggu ke $\mathrm{V}$ sebesar $0 \mathrm{Cm} / \mathrm{hari}$ atau pada minggu ke $\mathrm{V}$ tidak mengalami pertumbuhan lebar lengkung. Pada kelompok perlakuan II (P2) laju pertumbuhan lebar lengkung paling tinggi terjadi pada pengamatan minggu ke III yaitu sebesar $0.014286 \mathrm{~cm} /$ hari. Sedangkan laju pertumbuhan lebar lengkung karapaks yg paling kecil yaitu terjadi pada pengamatan minggu ke II dan VI sebesar $0 \mathrm{Cm} /$ hari atau pada minggu ke II dan VI tidak mengalami pertumbuhan lebar lengkung.

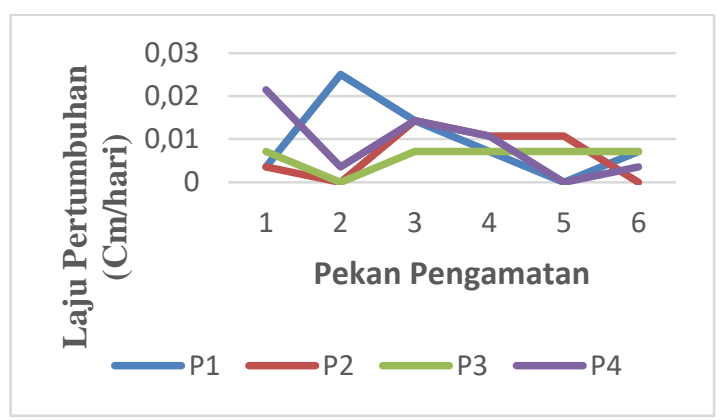

Gambar 6. Lebar lengkung karapak $S$. crassicollis selama 6 pekan di SBIH Ruyani P1 $=100 \%$ air sumur, $\mathrm{P} 2=50 \%$ air sumur $+50 \%$ air kolam, P3 $=75 \%$ air kolam $+25 \%$ air sumur, $\mathrm{P} 4=100 \%$ air kolam.

Pada kelompok perlakuan III (P3) laju pertumbuhan lebar lengkung paling tinggi terjadi pada pengamatan minggu ke I yaitu sebesar $0.007143 \mathrm{~cm} /$ hari. Sedangkan laju pertumbuhan lebar lengkung karapaks yg paling kecil yaitu terjadi pada pengamatan minggu ke II sebesar 0 $\mathrm{cm} /$ hari atau pada minggu ke II tidak mengalami pertumbuhan lebar lengkung. Sedangkan pada kelompok perlakuan IV (P4) laju pertumbuhan lebar lengkung paling tinggi terjadi pada pengamatan minggu ke I yaitu sebesar 0.021429 $\mathrm{cm} /$ hari. Sedangkan laju pertumbuhan lebar lengkung karapaks yg paling kecil yaitu terjadi pada pengamatan minggu ke $\mathrm{V}$ sebesar $0 \mathrm{~cm} / \mathrm{hari}$ atau pada minggu ke $\mathrm{V}$ tidak mengalami pertumbuhan lebar lengkung.

Laju pertumbuhan lebar lengkung karapaks $S$. crassicollis seperti yang terlihat pada gambar $6 \mathrm{Di}$ atas yang memiliki rata-rata laju pertumbuhan yang berbeda-beda,tetapi perbedaan rata-rata laju pertumbuhan lebar lengkung karapaks tidak secara signifikan terlihat perbedaan.Menurut Highfield (2007) faktor yang mempengaruhi perkembangan kura-kura adalah air dan suhu, dimana air yang kotor dapat menyebabkan penyakit seperti bakteri dan parasite. Sedangkan pada penelitian ini yang menggunakan media air sumur dan air kolam sama-sama memiliki kualitas air yang baik, sehingga laju pertumbuhan pada setiap kelompok perlakuan tidak berbeda nyata/tidak signifikan.

\section{Kombinasi air untuk setiap parameter pertumbuhan (dalam \%) S. crassicolis}

Tabel 1. Kombinasi air untuk setiap parameter pertumbuhan (dalam \%) S.crassicolis

\begin{tabular}{|c|c|c|c|c|c|c|}
\hline \multirow{2}{*}{$\begin{array}{c}\text { Perlak } \\
\text { uan }\end{array}$} & \multicolumn{5}{|c|}{ Parameter Pertumbuhan (\%) } \\
\cline { 2 - 7 } & Berat & $\begin{array}{c}\text { Pjg } \\
\text { karap } \\
\text { ak }\end{array}$ & $\begin{array}{c}\text { Lebar } \\
\text { karapa } \\
\text { ks }\end{array}$ & $\begin{array}{c}\text { Pjg } \\
\text { lengku } \\
\text { ng } \\
\text { karpks }\end{array}$ & $\begin{array}{c}\text { Lebar } \\
\text { gkung } \\
\text { karapak }\end{array}$ & $\begin{array}{c}\text { Tebal } \\
\text { Badan }\end{array}$ \\
\hline P1 & 1.106 & 2.9 & 2.096 & 1.058 & 2.584 & 2.602 \\
\hline P2 & 1.378 & 1.283 & 0.910 & 1.314 & 1.681 & 1.048 \\
\hline P3 & 1.207 & 2.325 & 1.451 & 0.562 & 1.633 & 11.698 \\
\hline P4 & 1.042 & 1.267 & 1.001 & 0.727 & 2.604 & 1.992 \\
\hline
\end{tabular}

Berdasarkan Tabel 1 dapat dilihat kombinasi air yang mana yang paling sesuai bagi pertumbuhan S. crassicolis. Dapat dilihat bahwa hanya pada kelompok perlakuan P1 dan P2 yang 
mengalami laju pertumbuhan, karena pada kelompok perlakuan 3 dan 4 secara rata-rata tidak mengalami pertumbuhan. Tetapi perbedaan ini tidak berbeda secara signifikan.

Berdasarkan Tabel 1, dapat dilihat bahwa pemberian air sumur yang paling cocok, karena pada kelompok perlakuan 2(P2) dengan $50 \%$ air sumur $+50 \%$ air kolam memiliki laju pertumbuhan $S$. crassicolis paling tinggi. Ini menunjukkan bahwa pemberian dengan kombinasi air kolam dan air sumur sebagai acuan kecocokan lokasi konservasi ex situ bagi $S$. crassicolis, karena perbedaan rata-rata laju pertumbuhan pada setiap kelompok perlakuan tidak terlihat berbeda signifikan/tidak berbeda nyata. Ada kemungkinan kurangnya laju pertumbuhan pada kelompok perlakuan 2, 3 dan 4 bukan hanya karena faktor air melainkan disebabkan oleh faktor sensitifitas dari kura-kura itu sendiri. Dengan kata lain air kolam area target konservasi dapat direkomendasikan untuk digunakan sebagai lokasi konservasi Ex situbagi S. crassicolis.

\section{KESIMPULAN}

Kesimpulan dalam penelitian ini antara lain: a) Pada penelitian ini, pemberian air sumur secara statistic merupakan media yang paling cocok, karena pada kelompok perlakuan 2(P2) dengan $50 \%$ air sumur $+50 \%$ air kolam memiliki laju pertumbuhan $S$. crassicolis paling tinggi. Namun, laju pertumbuhan $S$. crassicolis dengan pemberian dengan kombinasi air kolam tidak terlihat perbedaan yang signifikan dibandingkan air sumur yang nantinya akan di gunakan sebagai lokasi konservasi ex situ bagi S. crassicolis.

Saran dalam penelitian ini antara lain: 1) Perlu adanya penelitian lanjutan yang dilakukan di area konservasi kura-kura untuk mengetahui pertumbuhan s.crassicollissecara efektif, 2) sebaiknya untuk penelitian selanjutnya rancangan pembelajarannya benar-benar dilakukan di area konservasi langsung sebagai pembelajaran pratikum outdoor.

\section{DAFTAR PUSTAKA}

Andrea, J. (2011). Beraneka Ragam Reptil, PT Sandiarta Sukses, Bandung

Fithria, Abdi. (2008). Upaya Konservasi Bangsa Kura-Kura di Areal Penambangan Emas Dan Intan Catchment Area Riam Kanan, Kalimantan Selatan. Jurnal Hutan Tropis Borneo 24: 180-192.

Highfield C, A. (2007). catatan mengenai gizi utama untuk kura-kura dan efeknya pada pertumbuhan dan perkembangannya.www.Hewanpeliharaan.co $\mathrm{m}$ diakses tanggal 10 Mei 2016 jam 14.23 WIB

Indrawan,M dkk. (2012). Biologi Konservasi, Edisi Revisi, Yayasan Pustaka Obor Indonesia, Jakarta

Iskandar, D.T. (2000). Kura-kura dan Buaya Indonesia \& Papua Nugini.Departement Biology, Faculty of Mathematics and Natural Science.Institute of Technology Bandung. Bandung

IUCN. (2015). The IUCN Red List of Threatened Species: Siebenrockiella crassiocolis. http://www.iucnredlist.org/details/39616/0

Kurniati, Hellen. (2010). Kura-kura dan Bulus yang Diperdagangkan di Propinsi Jawa Tengah dan Yogyakarta. Fauna Indonesia 9(1): 10-14.

Nyberg. (2015). Adaptation vs Acclimatization. http://www.uic.edu/classes/bios/bios101/x209 _files/textmostly/index.htm.

Odum, E.P. (1971). Fundamentals of Ecology.W.B. Sondors Company Ltd. Philadelphia.

Ruyani, A. (2015). Mengenal Kura-Kura Air Tawar dan Teresterial di Bengkulu

Sari, G.M. (2012). Laju Konsumsi dan Pertumbuhan Kura-Kura Bajuku (Ortilia borneensis) yang diberi makan pellet, kangkung (Ipomea reptans), dan rucah ikan. Skripsi Program S1 FKIP Universitas Bengkulu 
Saggese, MD. (2009). Clinical Approach to The Anemic Reptile. J Exotic Pet Med 18(3): 98111.

Suhartoyo,H, dkk. (2016). Pendidikan Konservasi Kura-kura Sumatera (Modul 3), Unit Penerbitan FKIP UNIB.Bengkulu.
Wiryono. (2013). Pengantar Ilmu Lingkungan. Pertelon Media. Bengkulu 